\title{
Analysis of Influence of Motivation, Competence, Compensation toward Performance of Employee
}

\author{
Tati Hartati \\ Lecturer at Public Administration - Majalengka University, Indonesia \\ htati58@yahoo.com
}

\begin{abstract}
Motivation, competence, compensation and performance are important factors in an organization to achieve its stated goals. This study will examine empirically related to motivation, competence and compensation for its effect on employee performance. The research method used in this research is quantitative with survey techniques. The sample in this study were employees. Determination of the sample is done by proportional random sampling. Sources of data in this study are primary and secondary data. The analysis technique used in this study is path analysis. The results of the study prove that motivation, competence, compensation and performance are in the category of being headed well. While the results of verification studies prove that motivation, competence and compensation have a significant effect both partially and simultaneously on employee performance.
\end{abstract}

\section{Keywords}

motivation; competence; compensation and performance.

\section{Introduction}

An organization can run effectively if management functions such as planning, organizing, motivation and supervision that are functioning well, and the supporting elements are available and fulfilling the requirements. The relevant social context determines which categorization seems most suitable to provide a meaningful organization (Saragih et al 2019). One of the most important elements that can support the course of the company is human resources (employees). Human resources have an important role in determining the success of the company. Likewise with the Majalengka Regency PDAM, as a company that has the task of providing drinking water to the community and as a source of PAD. As an element of community service, it is demanded to be socially oriented, whereas as a source of PAD it is inseparable from the business aspect, which is looking for profit. The benefits obtained are expected to be able to contribute to regional income to finance government and development in the city of Majalengka. Regional Drinking Water Company (PDAM) of Majalengka Regency is one of the Majalengka Regency Owned Enterprises (BUMD) operating in Majalengka Regency in order to serve some of the people of Majalengka Regency in providing clean water services. In managing its business, PDAM has a variety of problems that surround company organizations, namely internal problems such as low service level, where PDAM Majalengka for service coverage only reaches $25.44 \%$.

Motivation is as a series of giving encouragement to someone to carry out actions to achieve the desired goals Sondang in Arif (2019). Motivation will cause impetus to someone who causes him to do certain actions to meet their needs. So work motivation is a psychological condition that encourages workers to make an effort to produce goods or services so that a goal can be achieved.

Some of the conditions above show the low performance of PDAM employees in Majalengka Regency. This of course depends on the role The problem of improving 
employee performance is closely related to the problem of how to motivate employees, how to implement a reward system, so that employees can and are willing to work optimally and so that they can support the achievement of company goals. The factors that affect a person's performance are very complex. Sutermeister (1976: 1) describes the factors which include; training and work experience, education, personality attitudes, organizational leaders, social conditions, individual needs, physical condition of the workplace, abilities, work motivation and so on. (Soelaiman, 2007) Ability and motivation are factors that interact with performance. A person's abilities can be determined by skills and knowledge, whereas skills can be influenced by skills. Personality and knowledge can be influenced by education, training experience and interests. Basically motivation can be sourced from a person or often known as internal motivation and can also be sourced from outside oneself or also called external motivation. Empirically and internally motivated motivation can improve performance (Shintya Ervina Donna Mundung., 2015). Several other researchers have in common that empirical motivation has a strong and positive influence on the formation of employee performance (Ek and Mukuru, 2013; Zameer, Ali and Amir, 2014; Karyono, 2018). Employee performance is also influenced by competency factors, this is in line with the results of previous studies that empirically prove that competence has a positive and significant effect on performance (Renyut et al., 2017; Mubarok, 2018; Mukhtar, 2018).

In addition, the provision of compensation is one of the important factors in influencing employee performance is the existence of fair and equitable compensation. Some of the results of previous studies have empirically confirmed that compensation has a positive and significant effect on employee performance (Ramzan et al., 2014; Darma et al., 2018; Dwianto and Aprurroji, 2019). Based on these descriptions, the authors are interested in conducting research on "Analysis of the Effects of Motivation, Competence, Work Motivation on Employee Performance".

\section{Reseach Method}

The method used in this research is to use descriptive and verification research methods. Source of data used in this study are primary data and secondary data. Primary data were obtained from survey results directly to the field using a research instrument in the form of a questionnaire to respondents, while secondary data were obtained from organizational data, the internet and scientific journals. In determining the sample, it is done by proportional random sampling, this is in accordance with the characteristics of the population and research. Determination of the sample by proportional random sampling. Before the data analysis is performed, the data is firstly carried out to test the instrument in the form of a validity and reliability test. After testing the validity and reliability, then the next step is to do a descriptive analysis of each variable and the final step is to test the hypothesis using path analysis.

\section{Discussion}

The independent variable (independent variable) in this study consisted of 3 variables, namely motivation (X1), competence (X2) and compensation (X3), which had ordinal measurement scale with a total number of questions of 60 items. While the employee performance variable which is a dependent variable with an ordinal measurement scale with a total number of questions is 20 items. 


\subsection{Descriptive Analysis of Research Variables}

The following is a description of each research variable. Motivational variables have the lowest scale 1 for strongly disagree answers to 5 for answers strongly agree with the statement submitted. Here is a table of the frequency distribution of variable X1 (motivation) based on data from the questionnaire results.

Table 1. Variable Frequency Distribution of Motivation

\begin{tabular}{|l|l|c|}
\hline No & Description & Score \\
\hline 1 & Mean & 81.0920 \\
\hline 2 & Mode & 81.0000 \\
\hline 3 & Standard deviation & 5.06844 \\
\hline 4 & Minimum & 67.00 \\
\hline 5 & Maximum & 94.00 \\
\hline
\end{tabular}

Source: SPSS Calculation Results Version 16, 2009

Work motivation variable shows the average value of 81.00 with a standard gap of 5.06. The mode value or the value that often appears shows 81.00 . The minimum average value is 67.00 and the maximum average value is 94 . Judging from the magnitude of the average value shows that the motivation for each employee who was made a respondent in choosing the answer to the questionnaire in general between hesitation to strongly agree with the statement submitted. From the score above can be determined the motivation is medium, high or very high motivation. Score $1=$ very low motivation, $2=$ low motivation, $3=$ moderate motivation, $4=$ high motivation and $5=$ very high motivation. The mean value of 81.00 indicates that respondents have moderate to very high motivation towards their work. The competency variable has the lowest scale 1 for answers that strongly disagree to 5 for answers strongly agree with the statement submitted. The following is a table of the frequency distribution of variable X2 (competency) based on data from questionnaire results.

Table 2. Frequency Distribution of Competency Variables

\begin{tabular}{|l|l|c|}
\hline No & Description & Score \\
\hline 1 & Mean & 82.0345 \\
\hline 2 & Mode & 80.00 \\
\hline 3 & Standard deviation & 4.90479 \\
\hline 4 & Minimum & 72.00 \\
\hline 5 & Maximum & 97.00 \\
\hline
\end{tabular}

Source: SPSS Calculation Results Version 16, 2009

The competency variable shows the average value of 82.0345 with the standard gap of 4.90479. The mode value or the value that often appears shows 80.00. The minimum average value is 72.00 and the maximum average value is 97.00 . Judging from the magnitude of the average value shows that the competence for each employee who was used as a respondent in choosing the answers to the questionnaire in general between hesitant to strongly agree with the statement submitted. From the scores above can be determined moderate competence, 
good or very good. Score $1=$ very low competency, $2=$ low competency, $3=$ moderate competency, $4=$ high competency and $5=$ very high competency. A mean value of 82.00 indicates that respondents have moderate to very high competence in their work. The compensation variable has the lowest scale 1 for answers that strongly disagree to 5 for answers strongly agree with the statement submitted. The following is a variable frequency distribution table X3 (compensation) based on data from the questionnaire results.

Table 3. Frequency Distribution of Compensation Variables

\begin{tabular}{|l|l|l|}
\hline No & Description & Score \\
\hline 1 & Mean & 80.1724 \\
\hline 2 & Mode & 82.00 \\
\hline 3 & Standard deviation & 2.90231 \\
\hline 4 & Minimum & 74.00 \\
\hline 5 & Maximum & 87.00 \\
\hline
\end{tabular}

Source: SPSS Calculation Results Version 16, 2009

The compensation variable shows the mean value of 80.1724 with a standard gap of 2.90231. The mode value or the value that often appears shows 80.00 . The minimum average value is 74.00 and the maximum average value is 87.00 . Judging from the magnitude of the average value shows that the competence for each employee who was used as a respondent in choosing the answers to the questionnaire in general between hesitant to strongly agree with the statement submitted. From the scores above can be determined moderate competence, good or very good. Score $1=$ very low compensation, $2=$ low compensation, $3=$ moderate compensation, $4=$ high compensation and $5=$ very high compensation. A mean value of 82.00 indicates that respondents have moderate to very high competence in their work. Teacher performance variables have the lowest scale 1 for strongly disagree answers to 5 for answers strongly agree with the statement submitted. The following is a variable frequency distribution table Y (employee performance) based on data from questionnaire results.

Table 4. Frequency Distribution of Employee Performance Variables

\begin{tabular}{|l|l|l|}
\hline No & Description & Score \\
\hline 1 & Mean & 81.9885 \\
\hline 2 & Mode & 81.00 \\
\hline 3 & Standard deviation & 4.47342 \\
\hline 4 & Minimum & 72.00 \\
\hline 5 & Maximum & 93.00 \\
\hline
\end{tabular}

Source: SPSS Calculation Results Version 16, 2009

Employee performance variable shows the average value of 81.9885 with the standard gap of 4.47342. The mode value or the value that often appears shows 81.00 . The minimum average value is 72.00 and the maximum value of organizational commitment is 93.00 . 
Judging from the magnitude of the average value shows that the performance of employees for each employee who was used as respondents in choosing the answer to the questionnaire in general between between doubtful to strongly agree with the statement submitted. From the scores above can be determined moderate competence, good or very good. Score $1=$ very low compensation, $2=$ low compensation, $3=$ moderate compensation, $4=$ high compensation and $5=$ very high compensation. A mean value of 82.00 indicates that respondents have moderate to very high competence in their work.

\subsection{Relationship of Exogenous Variables (X) with Community Satisfaction (Y)}

The results of the calculation of the correlation analysis between Tangible, Reliability, Responsiveness, Assurance and Empathy variables with the Community Satisfaction variable are presented in the table.

Table 5. Testing the Correlation Coefficient of Variable X with Variable Y

\begin{tabular}{|c|c|c|c|c|c|c|l|}
\hline No & Variable & r-count & T Score & $\begin{array}{c}\text { T- } \\
\text { Table }\end{array}$ & Sig. & Conclusion & Category \\
\hline 1 & $\mathrm{X}_{1} \mathrm{Y}$ & 0.692 & 8.847 & 1.98 & 0.00 & $\begin{array}{c}\text { Not } \\
\text { significant }\end{array}$ & $\begin{array}{l}\text { Very low } \\
\text { correlation }\end{array}$ \\
\hline 2 & $\mathrm{X}_{2} \mathrm{Y}$ & 0.936 & 24.51 & 1.98 & 0.00 & significant & $\begin{array}{l}\text { very high } \\
\text { correlation }\end{array}$ \\
\hline 3 & $\mathrm{X}_{3} \mathrm{Y}$ & 0.770 & 17.39 & 1.98 & 0.00 & significant & $\begin{array}{l}\text { Very High } \\
\text { correlation }\end{array}$ \\
\hline
\end{tabular}

Source: Correlation Analysis Results Data, 2008

From the Table ... above the significance value of the correlation between variables of organizational culture change and employee performance is 0,000 which is smaller than the real level $\square=0.05$ or by looking at the statistical value $\mid \mathrm{T}$ value $\mid>$ TTabel $=1991$, which means that there is a linear relationship between the variables of motivation, competence and compensation with employee performance. After analyzing the correlation coefficient, the next step in the path analysis is to analyze the path coefficient. The quantities that have been calculated are illustrated in the path diagram as shown below.

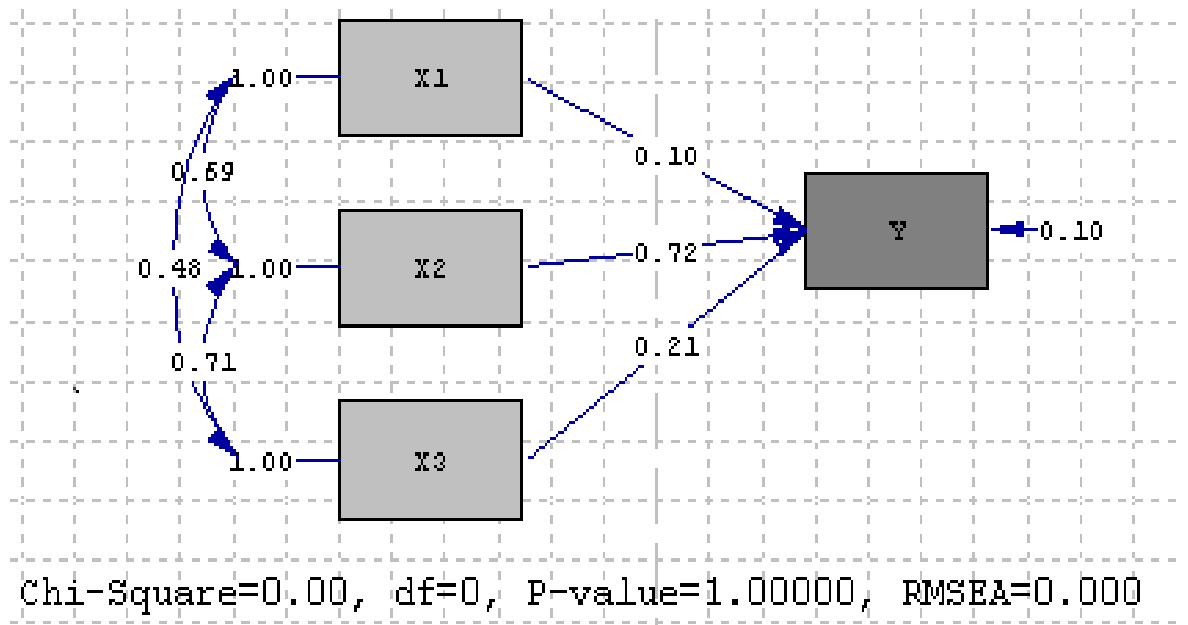

Source: LISREL 8.50,2009 
Figure 1. Motivation, Competence and Compensation Path Coefficients Towards Employee Performance

The structural models of motivation, competence and compensation for employee performance are as follows:

$$
\mathrm{Y}=0.10 \mathrm{X} 1+0.72 \mathrm{X} 2+0.21 \mathrm{X} 3 \mathrm{dan} \mathrm{e}=0.10
$$

In the above equation, the path coefficient values of motivation, competence and compensation for employee performance are likely to be positive or negative. A positive path coefficient means motivation, competence and compensation will improve employee performance, while a negative path coefficient will reduce employee performance. All exogenous variables as seen in Figure 1 are positive, meaning that all exogenous variables will have a positive influence on employee performance. From the results of this path analysis the magnitude of the path coefficient of the motivational variable (X1) to employee performance $(\mathrm{Y})$ is 0.10 , the competency path coefficient $(\mathrm{X} 2)$ to community satisfaction $(\mathrm{Y})$ is 0.70 and the compensation path coefficient (X3) to community satisfaction (Y) amounting to 0.21 . When only considering the motivation variable, other variables are considered constant, so if the motivation variable increases by one unit, it will increase employee performance by 0.10 units, as well as competence and compensation will increase employee performance by 0.10 and 0.72 units respectively. Based on the results of the analysis of the coefficient of determination that (R2) of 0.90 means that $90 \%$ of the variable performance of employees can be explained by the three variables, namely motivation, competence and compensation. Partially the influence of motivation on employee performance is $6.9 \%$. The results of this study reinforce the results of previous studies conducted (Sudiardhita., Budi Hartono., Herlitah., Tuty Sariwulan., 2018; Adam and Kamase, 2019), while the results of the study (Rasmi, Amiruddin, 2017) motivation and compensation also affect factors employee satisfaction. The results of this study indicate that taking into account motivation in the structural model will improve employee performance by $6.9 \%$, and the results of testing this variable are significant at 5\% significance level. The competency variable from the results of the path analysis has been proven to affect employee performance by $64.6 \%$. The results of this study support the results of previous studies (Rijanti, Priyono and Nugroho, 2017; Made Agus Wija Pradnyana., Anak Agung Putu Agung., 2018; Adam and Kamase, 2019). The results of this study provide an understanding that taking into account competency in the structural model will improve employee performance by $64.6 \%$, and the results of testing this variable are significant at 5\% significance level. While the total effect of compensation on employee performance is $16.7 \%$. The results of this study support previous research (Sudiardhita., Budi Hartono., Herlitah., Tuty Sariwulan., 2018; Nuray Akter., 2019; Onuorah Anthonia., Okeke., 2019). The results of this study provide an understanding that taking into account compensation in the structural model will improve employee performance by $16.7 \%$, and the results of testing this variable are significant at 5\% significance level.

\section{Conclusion}

Simultaneously work motivation, competence and compensation contribute significantly to employee performance together by $0.90(90 \%)$. While the remaining $0.10(10 \%)$ is determined by other variables. For example: leadership, organizational climate, work ethic, organizational culture, satisfaction, service loyalty, quality, productivity, and others. Based on the findings of this study it can be concluded that 
the hypothesis stating "work motivation, competence and compensation contribute simultaneously and significantly to employee performance is acceptable". Work Motivation as measured by employee performance has a positive and significant contribution to the level of employee performance. Thus the level of employee performance is explained by work motivation which directly contributes to employee performance by $1 \%$, while the total effect of work motivation on employee performance is $6.9 \%$. Based on the findings of this study it can be concluded that the hypothesis stating "work motivation significantly contributes to employee performance is acceptable". Competence as measured by employee performance has a positive and significant contribution to the level of employee performance. Thus the high or low performance of employees is explained by competencies that directly contribute to employee performance by $49 \%$, while the total effect of competence on employee performance is $64.4 \%$. Based on the findings of this study it can be concluded that the hypothesis stating "competence contributes significantly to customer loyalty is acceptable". Compensation as measured by employee performance has a positive and significant contribution to the level of employee performance. Thus the high or low performance of employees is explained by Compensation which directly contributes to employee performance by $4 \%$, while the total effect of competence on employee performance is $16.7 \%$. Based on the findings of this study it can be concluded that the hypothesis stating "Compensation contributes significantly to customer loyalty is acceptable".

\section{References}

Adam, F. and Kamase, J. (2019) 'The Effect Competence And Motivation To Satisfaction And Performance', International Journal of Scientific \& Technology Research, 8(03), pp. 132-140.

Arif, S. (2019). Influence of Leadership, Organizational Culture, Work Motivation, and Job Satisfaction of Performance Principles of Senior High School in Medan City, Budapest International Research and Critics Institute (BIRCI-Journal), P. 239-254.

Darma, P. S. et al. (2018) 'The Effect of Compensation on Satisfaction and Employees', Management and Economics Journal, 1(February), pp. 69-77. doi: 10.18860/mecj.v1i1.4524.

Dwianto, A. S. and Aprurroji, A. (2019) 'The Effect of Compensation on Employee Performance at PT . Sango Indonesia - Karawang', Jurnal Ekonomi \& Ekonomi Syariah, 2(1), pp. 178-187.

Ek, K. and Mukuru, E. (2013) 'Effect of Motivation on Employee Performance In Public Middle Level Technical Training Institutions In Kenya', International Journal of Advances in Management and Economics, 2(4), pp. 73-82.

Karyono, O. (2018) 'Faktor determinan motivasi dan disiplin kerja terhadap kinerja pegawai serta dampaknya pada mutu pelayanan pada dinas pemuda, olahraga, budaya dan pariwisata (disporabudpar) kabupaten majalengka', Proceeding STIMA, 1(1), pp. 348359.

Available

at:

https://scholar.google.com/citations?user=yUuxCLUAAAAJ\&hl=en\#d=gs_md_cita$\mathrm{d} \& \mathrm{u}=\% 2 \mathrm{Fcitations} \% 3 \mathrm{Fview}$ _op\%3Dview_citation\%26hl\%3Den\%26user\%3DyUuxCL UAAAAJ\%26citation_for_view\%3DyUuxCLUAAAAJ\%3ATyk4Ss8FVUC\%26tzom\%3D-420. 
Made Agus Wija Pradnyana., Anak Agung Putu Agung., N. L. (2018) 'The Effect of Competence on Employees 'Performance with Physical and Leadership Work Environment as Moderating Variables on CV. Bali Bhuana Garment Denpasar', IJSEGCE, 2(1), pp. 39-47.

Mubarok, E. S. (2018) 'The Influence of Training, Competence, and Motivation on Employees Performance of Workers Social Security Agency in Banten Province , Indonesia', Journal of Economics and Sustainable Development, 9(4), pp. 129-139.

Mukhtar, A. (2018) 'The Effect Of Competence And Organization Culture To Work Satisfaction And Employee Performance Of Sharia Banks In Makassar City', International Journal of Scientific \& Technology Research, 7(10).

Nuray Akter., M. M. H. (2019) 'Effect of Compensation on Job Performance : An Empirical Study Effect of Compensation on Job Performance : An Empirical Study', International Journal of Engineering Technology, Management and Applied Sciences, (August 2016).

Onuorah Anthonia., Okeke., I. A. I. (2019) 'Compensation Management and Employee Performance in Nigeria Compensation Management and Employee Performance in Nigeria', International Journal of Academic Research in Business and Social Sciences, 9(2), pp. 384-398. doi: 10.6007/IJARBSS/v9-i2/5552.

Ramzan, M. et al. (2014) 'Impact of Compensation on Employee Performance ( Empirical Evidence from Banking Sector of Pakistan ) Islamia University of Bahawalpur Research Scholars of Department of Management Sciences', International Journal of Business and Social Science, 5(2), pp. 302-309.

Rasmi, Amiruddin, S. H. (2017) 'Compensation and motivation Effect to Employees' Job Satisfaction', Hasanuddin Economics and Business Review, 1(2), pp. 162-167. doi: $10.26487 /$ hebr.v.

Renyut, B. C. et al. (2017) 'The effect of organizational commitment, competence on Job satisfaction and employees performance in Maluku Governor' s Office', IOSR Journal of Business and Management (IOSR-JBM), 19(11), pp. 18-29. doi: 10.9790/487X1911031829.

Rijanti, T., Priyono, B. S. and Nugroho, H. P. (2017) 'The Influence of Competence and Job Characteristics on Performance with Motivation as Mediating Variable at Regional Finance Agency of Tegal City', The Sixth International Conference on Entrepreneurship and Business Management, (Icebm), pp. 412-419.

Saragih, Hisarma et al. 2019. The struggle of Batak Simalungun for their identity in Church organization in Simalungun, Medan, Indonesia. Journal of Human Behavior in the Social Environment, 693-704.

Shintya Ervina Donna Mundung., S. P. (2015) 'The influence of Extrinsic and Intrinsic Motivation on Employee', Jurnal EMBA, 3(2), pp. 25-35.

Soelaiman, S. (2007) Manajemen Kinerja: Langkah Efektif untuk Membangun, Mengendalikan dan Evaluasi Kerja. Jakarta: Intermedia Personalia Utama.

Sudiardhita., Budi hartono., Herlitah., Tuty Sariwulan., S. I. N. (2018) 'The Effect of Compensation, Motivation of Employee and Work Satisfaction to Employee Performance PT . BANK XYZ ( Persero ) TBK', Academy of Strategic Management Journal, 17(4), pp. 1-14.

Zameer, H., Ali, S. and Amir, M. (2014) 'The Impact of the Motivation on the Employee' s Perfor mance in Beverage Industry of Pakistan', International Journal of Academic Research in Accounting, Finance and Management Sciences, 4(1), pp. 293-298. doi: 10.6007/IJARAFMS/v4-i1/630. 